\title{
Changing Planning Law in Africa: An Introduction to the Issue
}

\author{
Vanessa Watson
}

Published online: 3 June 2011

(C) Springer Science+Business Media B.V. 2011

Most countries in Africa inherited their planning law from former colonial powers. Many of these countries have since revised their planning law, but the attitudes and practices of politicians and planning professionals towards urban development still reflect the approaches enshrined in the older colonial laws. The continuation of these in a context where towns and cities have changed dramatically since the first half of the twentieth century probably represents one of the most important obstacles to successful long-term management of these urban centers. The aim of this special issue is to draw together a number of international experts on planning law in countries of the global South, to reflect on why changing these laws and practices is so difficult in Africa and what has happened where reforms have been attempted. The case of Brazil has been juxtaposed with the African cases to show how a progressive urban reform agenda can have far-reaching implications for planning law.

This special issue, and the imperative to change planning law so that it is a useful instrument for addressing twenty-first century urban issues in Africa, is part of a larger research and advocacy agenda which shapes the work of the African Centre for Cities at the University of Cape Town. The center takes as a starting point the fact that in $2007,38.7 \%$ of Africa's population was urban, but this is projected to rise to over $60 \%$ in 2050, implying a trebling of the continent's urban population (United Nations 2008). Future rapid urban growth in Africa also faces the particular problem of weak formal urban economies. In fact, Africa is the only continent where urbanization and urban economic growth have not been mutually reinforcing, leading to a situation where an impoverished urban populace survives largely under conditions of informality. It is estimated that $72 \%$ of the current urban population lives without acceptable shelter and services (UN-Habitat 2003), and the bulk of the urban population in most countries survives in the "informal sector" (GuhaKhasnobis and Kanbur 2006). In Africa, these factors are compounded by a deep

\footnotetext{
V. Watson $(\square)$

African Centre for Cities, School of Architecture, Planning and Geomatics, University of Cape Town,

Cape Town, South Africa

e-mail: Vanessa.Watson@uct.ac.za
} 
ambivalence towards urbanity and the reluctance by many leaders and governments to recognize the realities of city life in shaping the identity and politics of their subjects (Mamdani 1996). Given these concerns, the center seeks to shift mindsets to focus attention on the nature of the urban crisis in Africa and to identify and explore the triggers which can open the way for a more sustainable and inclusive urban future. We believe that planning law is one of these triggers.

In the colonial era, many African countries found themselves with national planning laws that were drawn directly from those in place in the home territories of the colonial administrations. These laws served in part to put in place a system of urban racial segregation between the colonizers and the colonized, but also to transfer what was believed would be an effective mechanism to bring about the orderly and controlled development of rapidly growing towns. As such, these laws were based on assumptions which included the presence of strong and wellresourced governments, and an availability of technical skills to enforce the laws; stable and law-abiding societies willing to support the allocation of powers of planning to government; a belief in the acceptability of freehold and private rights in land; faith in an approach to urban development based on controlling the use of land; and a conviction that the desired future growth of a city could be planned and achieved. While these laws did not necessarily dictate a particular urban form, they inevitably supported the then British and European vision of a well-planned, orderly city. At this point in time (pre and post-War), this vision involved the compartmentalization of the city into different use zones (residential, commercial, industrial, open space, and so on), low densities and plenty of green space (the Garden Cities concept), and a highly structured and car-oriented movement system. This vision was conceptualized and put in place by planning professionals who considered themselves as technical experts, who had no need to consult either with citizens or other interest groups. Needless to say, these early urban visions and the planning laws that supported them could not envisage rapid population growth, weak and under-resourced governments, informal and unregulated settlements, and street traders. The basic assumptions on which planning laws had been conceived simply did not hold.

Inevitably, as African countries moved into the post-colonial era and as urbanization began to outstrip the provision of employment, housing and services, the urban vision (which had only ever really been evident in colonial quarters of African cities) broke down and the now familiar pattern of informal settlement, rundown urban cores, an extensive informal economy, and rapidly spreading peri-urban areas, became the norm. The gap between the intentions of planning law and the actual reality of urban life grew wider until it became difficult to see a connection between the two. Yet, strangely, elements of colonial planning law persisted as did the institutional systems, the urban master plans, and the land use zoning schemes which the laws provided for. Planners were trained at universities to understand and operate these colonial systems and visions of the "good city," and after graduation, they were employed in government offices to produce more master plans which had little hope of ever being implemented (Diaw et al. 2002). Calls to change and update planning legislation to make it a more appropriate instrument to deal with the growing urban crises were generally heeded, and new laws were fashioned, but on the ground, there was little change. A major attempt by the United Nations Centre 
for Human Settlements and the World Bank in 1986 to introduce a new urban planning system, termed the Urban Management Program, became in many municipalities simply an "add on" to the existing planning system which continued as before. In 2009, the UN Habitat Global Report on Human Settlements declared that the persistence of outdated planning systems was a major blockage to addressing the problems of growing and poor cities, and a central reason for the exclusion of the poor in many cities of the global South, including in Africa.

The question as to why reformed planning laws in Africa have been so hard to implement is addressed in the first article of this issue. Stephen Berrisford ${ }^{1}$ points to one central reason that is compelling: planning law was used by colonial regimes to support the interests of a small urban minority elite, and it still continues to do that, although the nature of the minority has changed. What minority elites gain from outdated planning approaches can vary. For political leaders, planning law can be a useful instrument to attack the land and livelihoods of suspected opposition supporters. This was one possible reason for Zimbabwe's Operation Murambatsvina in 2005 (also termed Restore Order, Cleanup, and Drive out the Rubbish) carried out under the Town and Country Planning Act of 1976 (chapter 29:12), which authorizes the state to demolish structures and evict people. Conservative estimates were that 700,000 people were evicted from their homes and 2.3 million people were affected in other ways. No compensation was paid or alternative homes offered (Berrisford and Kihato 2006). Another use of planning laws is to carry out the evictions and removals of people who may be in the way of planned city beautification projects, such as the construction of the new capital Abuja in Nigeria. By 2006, 800,000 people had been evicted from land that was "zoned for other purposes under the Abuja Master Plan," and in some cases, this land has been allocated to private developers (COHRE 2006). Both these actions point to another possible reason for the reluctance to move towards new planning law; the decentralized control it offers to municipal governments leaves national politicians feeling threatened by urban political opposition parties and by growing numbers of disaffected rural migrants intent on retaining a foothold in the city. Furthermore, in many African cities, private commercial investment has become a major driver of urban change: outdated planning laws and plans which leave much of the city unregulated open up all kinds of opportunities for corruption or land deals which play to the interests of the elite. Roy's (2009) comment on a similar feature of planning in Indian cities argues that the planning system has been "informalized" allowing the declaration of legality and illegality to suit the interests of those in power, politically and financially. In the periurban areas of Indian cities, regulation is withheld, allowing the state considerable "territorial flexibility" to alter land use and acquire land for urban and industrial development.

This special issue addresses the need to change planning law in Africa from a number of different perspectives. In the first article, Berrisford examines the attempts that have been made to change planning law. Usually initiated by international development agencies, there is a common failure to fully understand the complex nature of socio-economic systems in African cities and the interests of various parties with a stake in planning law. Assumptions that introducing new planning law

\footnotetext{
${ }^{1}$ See article entitled: Why it's difficult to change urban planning laws in African countries.
} 
is a simple technical process of writing new legislation always prove to be unfounded. Arguing that it is necessary and important to change planning laws and practices in Africa, Berrisford sets out some principles and an approach to guide this. He makes the crucial point that deep attitudinal shifts are required as a pre-requisite for these changes. ${ }^{2}$

The next two articles in the issue, both by Stephen Berrisford, describe two case studies of planning law reform in which he was personally involved. He uses the case of Zambia $^{3}$ to support his argument that any process of planning law reform should be incremental, targeting key areas of law for amendment, rather than attempting a wholesale change. Reflecting on the process that had been followed by the consultants, he describes how time and cost limitations inevitably curtailed deep engagement with various stakeholders and left the consultant team wondering why there had been so little internal debate on changing this fundamental piece of legislation. At this stage, the regulations attached to the Bill have not been drafted, and hence, the new law has not yet been implemented, nearly 2 years after the consultants had finished their work.

Attempts to change planning law in South Africa have been particularly disappointing. Some 18 years after the end of apartheid, and the introduction of democratic government and a highly progressive constitution, apartheid planning laws remain in place. This is despite the fact that planning was a key tool of the apartheid government enabling it to put in place urban racial segregation. Despite numerous national policy statements calling for integrated, sustainable, and inclusive urban development, and despite the early introduction of interim planning legislation (the 1995 Development Facilitation Act, since withdrawn) which set out a process for replacing apartheid planning, this has not yet occurred. While every other aspect of law entrenching racial apartheid has been reformed since 1994, apartheid planning law remains in force. In this respect, planning law reform processes in South Africa have much in common with those in other parts of the continent. In his third article in this issue ${ }^{4}$, Berrisford identifies the various windows of opportunity which opened up to allow planning reform to proceed and the reasons why progress has stalled. In South Africa, it has been particularly difficult to frame planning legislation which aligns with the constitutional definitions of planning. But there have been other difficulties as well, such as the constitutional protection of property rights, the pattern of which was set in place under apartheid, and the problematic institutional location of the planning function in a department concerned largely with rural development. A new bill is due before parliament this year, and this may finally pave the way for new legislation.

In the fourth article in this issue ${ }^{5}$, Stuart Wilson takes on the question of how the lack of planning for well-located and affordable housing in South African cities results in many poor families occupying land and buildings "illegally". When these

\footnotetext{
$\overline{2}$ One way to start to shift attitudes is through planning education. To this end, the Association of African Planning Schools (http://www.africanplanningschools.org.za/) has been engaged in a project entitled Revitalising Planning Education in Africa, with support from the African Centre for Cities.

${ }^{3}$ See article entitled: Revising Spatial Planning Legislation in Zambia: a Case Study

${ }^{4}$ See article entitled: Unraveling apartheid spatial planning legislation in South Africa: a case study.

${ }^{5}$ See article entitled: Planning for inclusion in South Africa: the state's duty to prevent homelessness and the potential of "meaningful engagement".
} 
sites are identified as development opportunities, by the public or private sectors, then eviction is a common mechanism used to clear the way for development projects. While the law has gradually been changed to protect the evicted from homelessness, municipal practices have been slow to catch up. Wilson examines shifts in the law regarding eviction and homelessness, culminating in a recent precedent-setting decision by the constitutional court which has important implications for local urban planning. Wilson concludes with a case of relatively successful relocation where municipal engagement with a community marked for eviction was able to produce a satisfactory outcome.

The last two articles in the issue consider what planning law could be like if the way was open for radical law reform. In post-conflict situations, where previous laws and practices have been swept away, the opportunity sometimes exists to put something fundamentally new in place. In the fifth article in this issue ${ }^{6}$, Patrick McAuslan reports on his experience of drafting an approach to transformational planning law for the post-conflict country of Liberia, particularly its capital city of Monrovia, in West Africa. McAuslan argues for policies and laws based on the concept of the Right to the City, as has happened in Brazilian and Turkish urban law. In Liberia, this would imply a total transformation of the administrative and land tenure cultures of the country. He outlines the preconditions for and basics of an urban transformation law which would pave the way for a radically different approach to managing issues of informality and tenure in a rapidly growing African city, and speculates as to why there seems to be little sense of urgency in Liberia to take up these ideas.

In the last article ${ }^{7}$, Edesio Fernandes discusses how legal-urban reform in Brazil has successfully managed to put in place a legal order which consolidates the notion of the Right to the City. In Brazil, this has been neither quick nor simple. Begun in the late 1980s, it has required much more than the simple drafting of new laws: rather, it has taken wide-ranging institutional, policy, legal and socio-political change at all levels of government; the drafting since 2001 of new participatory urban plans and massive resources channeled into infrastructure and land regularization since 2007. Most significantly, Fernandes argues, it requires an ongoing social and political mobilization in which the urban poor continually assert and claim their rights to the city. While Brazil certainly represents a successful case of legal reform, Fernandes cautions that problems remain. There are growing conflicts over the use of urban land fuelled by economic growth, and the new master plans have not always been able to achieve spatial integration - their adherence to the tradition of regulatory planning is partly to blame here.

Brazil is a very different context to Africa, but with regard to urban issues of exclusion, rampant property speculation and serious environmental concerns, there are strong commonalities. If there is one lesson to learn from the Brazil case, it is that planning law reform cannot be a quick fix by a team of outside consultants: it needs to be a long-term and deeply embedded process with buy-in from all urban sectors to a fundamentally different way of approaching urban development and

\footnotetext{
${ }^{6}$ See article entitled: Urban planning law in Liberia: the case for a transformational approach.

${ }^{7}$ See article entitled: Implementing the urban reform agenda in Brazil: possibilities, challenges, and lessons
} 
change. Brazil has moved a long way down this road. The cost for African countries of not giving serious consideration to this area of reform raises the specter of future cities in serious socio-political and spatial crisis.

\section{References}

Berrisford, S., \& Kihato, M. (2006). The role of planning law in evictions in sub-Saharan Africa. South African Review of Sociology, 37(1), 20-34.

COHRE (2006). Forced evictions: violations of human rights (10), Geneva.

Diaw, K., Nnkya, T., \& Watson, V. (2002). Planning education in Africa: responding to the demands of a changing context. Planning Practice and Research, 17(3), 337-348.

Guha-Khasnobis, B., \& Kanbur, R. (2006). Introduction: informal labour markets and development. In B. Guha-Khasnobis \& R. Kanbur (Eds.), Informal labour markets and development. New York: Palgrave Macmillan.

Mamdani, M. (1996). Citizen and subject: contemporary africa and the legacy of late colonialism. Princeton: Princeton University Press.

Roy, A. (2009). Why India cannot plan its cities: informality, insurgence and the idiom of urbanization. Planning Theory, 8(1), 76-87.

UN Habitat (2009). Planning Sustainable Human Settlements, Global Report on Human Settlements. Nairobi.

UN-Habitat (United Nations Human Settlements Programme). (2003). The challenge of slums. Global Report on Human Settlements. London: Earthscan.

United Nations. (2008). World urbanization prospects: the 2007 revision (Highlights). New York: Department of Social and Economic Affairs, Population Division, UN. 